\title{
Temporal Patterns of Gonadotropin-Releasing Hormone (GnRH), c-fos, and Galanin Gene Expression in GnRH Neurons Relative to the Luteinizing Hormone Surge in the Rat
}

\author{
Patricia D. Finn, ${ }^{1}$ Robert A. Steiner, ${ }^{1,2,3}$ and Donald K. Clifton ${ }^{2,3}$ \\ Departments of ${ }^{1}$ Physiology and Biophysics and ${ }^{2}$ Obstetrics and Gynecology and ${ }^{3}$ The Population Center for Research in \\ Reproduction, University of Washington, Seattle, Washington 98195
}

Gonadotropin-releasing hormone $(\mathrm{GnRH})$ neurons increase their expression of Fos and galanin coincident with the luteinizing hormone (LH) surge in the female rat. To define the temporal relationships between the expression of these genes and the $\mathrm{GnRH}$ gene itself and to gain insight about the possible functional interactions of these processes, we compared levels of c-fos, galanin, and $\mathrm{GnRH}$ mRNA in $\mathrm{GnRH}$ neurons and plasma levels of $\mathrm{LH}$ in the rat, beginning $6 \mathrm{hr}$ before and continuing for $24 \mathrm{hr}$ after a sex steroid-induced LH surge. LH levels were increased significantly by $1600 \mathrm{hr}$. They increased twofold further by $1800 \mathrm{hr}$ and then returned to baseline by $2400 \mathrm{hr}$. Using in situ hybridization, we determined that levels of c-fos mRNA in GnRH neurons were elevated significantly at $1600 \mathrm{hr}$ only, whereas levels of galanin mRNA in GnRH neurons first increased twofold by $1800 \mathrm{hr}$, increased an additional

On the afternoon of proestrus in the rat, the combined actions of estrogen (E) and progesterone $(\mathrm{P})$ increase the release of gonadotropin-releasing hormone $(\mathrm{GnRH})$, which in turn induces a preovulatory surge of luteinizing hormone $(\mathrm{LH})$ (see Freeman, 1994). Although the precise sequence of molecular events mediating this phenomenon is poorly understood, several key intermediates have been identified, and these may provide insights into the overall process. The immediate early gene products Fos and Jun are induced in some GnRH neurons during the LH surge (Lee et al., 1990a, 1992a). This induction appears to be inseparable from the occurrence of the $\mathrm{LH}$ surge and dependent on synaptic transmission (Lee et al., 1990a, 1993). This suggests that increased transcription of one or more genes in GnRH neurons accompanies the release of $\mathrm{GnRH}$ and may be responsible for initiating events that are crucial for either the enhancement of GnRH secretion during the surge or replenishment of depleted stores of GnRH or other gene products in these cells after the surge.

\footnotetext{
Received Sept. 22, 1997; revised Nov. 4, 1997; accepted Nov. 5, 1997.

This work was supported by United States Public Health Service National Institutes of Health Grants RO1 HD27142 and T32 HD07453 and by the Mellon Foundation. We express our appreciation to Emilia Kabigting, Yvonne Chan, and Darouny Phosarath for their excellent technical skill and assistance in performing these experiments and Dr. William Bremner and the laboratory staff of the Population Center for Research in Reproduction Assay Core for performing the LH assays. We also thank MeiLan King, who contributed to the early phases of this work as part of her honors thesis for graduation from the University of Washington with honors.

Correspondence should be addressed to Dr. Donald K. Clifton, Department of Obstetrics and Gynecology, Box 356460, University of Washington, Seattle, WA 98195.

Copyright (C) 1998 Society for Neuroscience $\quad 0270-6474 / 98 / 180713-07 \$ 05.00 / 0$
}

twofold by $2400 \mathrm{hr}$, and remained elevated at all time points sampled thereafter. There were no significant changes in cellular levels of $\mathrm{GnRH}$ mRNA over the time points sampled. These results are consistent with the hypothesis that the induction of c-fos gene expression in $\mathrm{GnRH}$ neurons leads to an increase in galanin gene expression, and that the sustained increase in galanin mRNA levels in $\mathrm{GnRH}$ neurons reflects either the need to replenish galanin stores that are depleted at the time of the $\mathrm{LH}$ surge or the involvement of galanin with physiological events that occur on the day of estrus.

Key words: gonadotropin-releasing hormone; luteinizing hormone-releasing hormone; c-fos; galanin; in situ hybridization; luteinizing hormone; reproduction; neuroendocrine regulation

GnRH and galanin are coexpressed in GnRH neurons in the female rat (Coen et al., 1990; Merchenthaler et al., 1990; Marks et al., 1992), and their genes are plausible targets for activation by Fos and Jun (Bond et al., 1989; Anouar et al., 1994). Reports on whether a rise in GnRH gene expression subserves the occurrence of the $\mathrm{GnRH}$ and $\mathrm{LH}$ surge have been equivocal and conflicting (see Sagrillo et al., 1996); however, galanin mRNA levels in GnRH neurons clearly increase during the LH surge (Marks et al., 1993, 1994). As is the case with the expression of Fos in GnRH neurons, the increase in galanin expression is inseparable from the occurrence of the LH surge and is dependent on synaptic activation of GnRH neurons (Lee et al., 1990a, 1993; Marks et al., 1994; Rossmanith et al., 1996a). Although these observations point toward an activation of galanin gene expression in GnRH neurons at the time of the LH surge, other work from our laboratory suggests that galanin gene expression in GnRH neurons is also activated (as measured by elevated mRNA levels) on estrus $24 \mathrm{hr}$ after the preovulatory LH surge (Marks et al., 1993). Therefore, the precise role that galanin plays in these neurons remains unclear.

If Fos activates either galanin or GnRH gene expression in GnRH neurons, then c-fos mRNA levels should increase immediately before a detectable rise in these mRNAs. Furthermore, if either GnRH or galanin is involved in the generation of the LH surge, one would predict that their messages would increase before the surge and decline after its completion. To help clarify the physiological roles of c-fos, galanin, and GnRH in GnRH neurons and to determine the temporal relationships among these parameters, we measured circulating LH levels and cellular levels of c-fos, galanin, and GnRH mRNAs in GnRH neurons in ovariec- 
tomized rats over a $30 \mathrm{hr}$ period bracketing a steroid-induced $\mathrm{LH}$ surge.

\section{MATERIALS AND METHODS}

\section{Animals}

Adult, 60-d-old female Sprague Dawley rats were obtained from Simonsen Laboratories (Gilroy, CA). They were maintained under constant temperature and a 14/10 hr light/dark cycle with lights on at $0700 \mathrm{hr}$. They were given free access to tap water and rat chow. Ovariectomies were performed under Ketamine $(100 \mathrm{mg} / \mathrm{ml}) /$ Xylazine $(20 \mathrm{mg} / \mathrm{ml})$ anesthesia mixed at a ratio of 5.0:1.6. Rats were handled four to five times weekly until killed. All procedures were approved by the Animal Care Committee of the School of Medicine at the University of Washington in accordance with the National Institutes of Health Guide for Care and Use of Laboratory Animals.

\section{Experimental design}

Experiment 1. Before assessing c-fos, GnRH, and galanin mRNA expression during the LH surge, a preliminary experiment was conducted to determine the precise temporal pattern of $\mathrm{LH}$ release in response to steroid priming. Eleven rats were ovariectomized and allowed to recover for 3 weeks. On day 0 at $1030 \mathrm{hr}$ the animals were injected with estradiol benzoate $\left(\mathrm{E}_{2} \mathrm{~B} ; 30 \mu \mathrm{g}\right.$ in $0.2 \mathrm{ml}$ of peanut oil, s.c.). On day 1 cannulae were implanted into the right atrium as described previously (Steiner et al., 1982). On day 2 at $1200 \mathrm{hr}, \mathrm{P}(5 \mathrm{mg} / 0.1 \mathrm{ml}$, s.c.) was injected, and serial blood samples were drawn at 1400, 1600, 1700, 1800, 1900, 2000, 2200 , and $2400 \mathrm{hr}$. An additional blood sample was collected at $0200 \mathrm{hr}$ on day 3. The serum was frozen for subsequent determination of $\mathrm{LH}$ concentration by radioimmunoassay (RIA).

Experiment 2. To determine the temporal pattern of cellular levels of the mRNAs coding for GnRH, c-fos, and galanin in GnRH neurons during the course of the LH surge, nine sets of female rats were ovariectomized, and 3-4 weeks later, they were treated with $\mathrm{E}_{2} \mathrm{~B}$ and $\mathrm{P}$ as described for Experiment 1 . Sets of rats $(n=4-6)$ were killed on day 2 at $1200 \mathrm{hr}$ (before P injection), 1400, 1500, 1600, 1800, and $2400 \mathrm{hr}$ and on day 3 at 0600,1200 , and $1800 \mathrm{hr}$.

\section{Tissue preparation}

After asphyxiation with $\mathrm{CO}_{2}$, the rats were decapitated immediately. Their brains were rapidly removed, frozen on dry ice, and stored at $-80^{\circ} \mathrm{C}$. Trunk blood was collected and serum was stored at $-20^{\circ} \mathrm{C}$ until assayed for LH contents. Twenty-micrometer-thick coronal brain sections were cut on a cryostat, thaw-mounted onto SuperFrost glass slides (Fisher Scientific, Fair Lawn, NJ), and stored in airtight boxes at $-80 \mathrm{C}$ until used in the assay. Sections were collected beginning at the level of Plate 16, according to the rat atlas of Paxinos and Watson (1986), and ending at the level of the caudal aspect of the decussation of the anterior commissure $(\sim 0.08 \mathrm{~mm}$ rostral to Plate 21$)$. The tissue sections were collected onto four sets of slides, each one representing a one-in-four series of sections.

\section{Riboprobe preparation}

${ }^{35}$ S-labeled GnRH cRNA probe The original plasmid containing a 462 bp insert complementary to prepro-GnRH (Adelman et al., 1986) was generously provided by Dr. Anthony Mason (Genentech, South San Francisco, CA). The insert, which is complementary to 170 bases of $5^{\prime}$ untranslated message, the entire 276 bases of open reading frame, and the first 16 bases of $3^{\prime}$ untranslated message, was subcloned into pGEM 4 (Marks et al., 1992). SalI was used to linearize the cDNA. The ${ }^{35} \mathrm{~S}$-labeled cRNA antisense probe was synthesized in vitro using an Ambion (Austin, TX) MAXIscript kit in the presence of $50 \mu \mathrm{M} \alpha$-thioUTP (New England Nuclear, Boston, MA), of which $14 \%$ was ${ }^{35}$ Slabeled and $86 \%$ was unlabeled. Yeast tRNA was added as carrier, and the cRNA probe was separated from unincorporated nucleotides with a Sephadex G-50 column (Boehringer Mannheim, Indianapolis, IN).

${ }^{35}$ S-labeled galanin $c R N A$ probe. The plasmid vector Bluescript (Stratagene, La Jolla, CA) containing a cDNA to rat galanin mRNA was provided by Drs. Henry Friesen and Maria Vrontakis (University of Manitoba, Winnipeg, Manitoba, Canada) (Vrontakis et al., 1987). The 680 bp insert is complementary to 124 bases of $5^{\prime}$ untranslated message, the entire 372 bases of open reading frame, and 184 bases of $3^{\prime}$ untranslated message. HindIII was used to linearize the cDNA. The ${ }^{35} \mathrm{~S}$-labeled cRNA antisense probe was synthesized in vitro in a reaction containing the following ingredients: $50 \mu \mathrm{M} \alpha$-thio-UTP, of which $25 \%$ was ${ }^{35} \mathrm{~S}$ - labeled and the remaining $75 \%$ was unlabeled; linearized cDNA (1 $\mu \mathrm{g} / \mu \mathrm{l})$; T7 RNA polymerase (2 U/ $\mu \mathrm{l}$, Boehringer Mannheim); $1 \times$ transcription buffer (provided with polymerase); $500 \mu \mathrm{M}$ ATP, CTP, and GTP; RNase inhibitor (4 U/ $\mu \mathrm{l})$; and $10 \mathrm{~mm}$ dithiolthreitol (DTT). Residual DNA was digested with $0.5 \mathrm{U} / \mu \mathrm{l}$ DNase, and the DNase reaction was stopped by adding $80 \mathrm{~mm}$ EDTA. Yeast tRNA was added as carrier, and the cRNA was purified with a Sephadex G-50 column.

${ }^{33} P$-labeled $c$-fos $c R N A$ probe. The original plasmid (pSP65) containing the rat c-fos insert was generously provided by Dr. Tom Curran (Roche Institute of Molecular Biology, Nutley, NJ) (Curran et al., 1987). A 1352 bp EcoRI and XhoI fragment of the cDNA was subcloned into pBluescript S/K (Burton et al., 1995). The cDNA was linearized with EcoRI, and the ${ }^{33} \mathrm{P}$-labeled antisense cRNA probe was synthesized in vitro using an Ambion MAXIscript kit in the presence of 12.5 pmol of $\left[{ }^{33} \mathrm{P}\right] U T P$ (DuPont NEN, Wilmington, DE). Yeast tRNA was added as carrier, and the cRNA probe was purified with an NENsorb column (DuPont NEN).

Digoxigenin-labeled GnRH cRNA probe. The digoxigenin-labeled cRNA probes for GnRH mRNA were synthesized in vitro in reactions containing the following ingredients: linearized DNA $(1 \mu \mathrm{g} / \mu \mathrm{l}) ; 1 \times$ digoxigenin DNA labeling mixture (Boehringer Mannheim); SP6 RNA polymerase ( $2 \mathrm{U} / \mu \mathrm{l}$; Boehringer Mannheim); $1 \times$ transcription buffer (provided with polymerase); RNase inhibitor (2 U/ $\mu \mathrm{l}$ ); and $10 \mathrm{~mm}$ DTT. Residual DNA was digested with $0.5 \mathrm{U} / \mu$ l DNase. The DNase reaction was stopped by adding $80 \mathrm{~mm}$ EDTA. The cRNA probe was separated from unincorporated nucleotides with a Sephadex G-50 column. The final concentrations of the digoxigenin-labeled GnRH probes were determined to be optimal based on preliminary test assays.

\section{Single-label in situ hybridization}

${ }^{35}$ S-labeled GnRH. To identify cells containing GnRH mRNA, we performed single-label in situ hybridization based on previously published protocols (Wiemann et al., 1990; Marks et al., 1992) with slight modifications. In brief, tissue sections were fixed, acetylated, and delipidated. Next, hybridization solution [freshly denatured ${ }^{35} \mathrm{~S}$-labeled $\mathrm{GnRH}$ probe $\left(0.30 \mu \mathrm{g} \cdot \mathrm{ml}^{-1} \cdot \mathrm{kb}^{-1}\right)$ and yeast tRNA $(2 \mathrm{mg} / \mathrm{ml})$ in hybridization buffer consisting of $52 \%$ deionized formamide, $10 \%$ dextran sulfate, $0.3 \mathrm{M}$ $\mathrm{NaCl}, 8 \mathrm{~mm}$ Tris, $\mathrm{pH} 8.0,0.08 \mathrm{~mm}$ EDTA, $0.02 \%$ bovine serum albumin, $0.02 \%$ Ficoll, $0.02 \%$ polyvinylpyrrolidone, and $200 \mathrm{~mm} \mathrm{DTT}$ ] was applied to the tissue $(30 \mu \mathrm{l} / \mathrm{slide})$. The slides were covered with silanecoated glass coverslips and incubated in humid chambers overnight at $51^{\circ} \mathrm{C}$. The next day the tissue was treated with RNase-A and washed under conditions of increasing stringency, including a $30 \mathrm{~min}$ wash at $60^{\circ} \mathrm{C}$ in $0.1 \times \mathrm{SSC}$. The tissue was then dehydrated in alcohols and air-dried. The slides were dipped in Kodak (Rochester, NY) NTB-2 emulsion diluted 1:1 in $600 \mathrm{~mm}$ ammonium acetate, exposed for $8 \mathrm{~d}$, developed, and counterstained with cresyl violet.

\section{Double-label in situ hybridization}

${ }^{35}$ S-labeled galanin and digoxigenin-labeled GnRH. To identify cells containing both GnRH mRNA and galanin mRNA, we performed doublelabel in situ hybridization following a protocol described previously (Marks et al., 1992; Finn et al., 1996) with slight modifications. The tissue sections were fixed, acetylated, and delipidated. Next, hybridization solution [freshly denatured ${ }^{35}$ S-labeled galanin probe $(0.25$ $\mu \mathrm{g} \cdot \mathrm{ml}^{-1} \cdot \mathrm{kb}^{-1}$ ), digoxigenin-labeled $\mathrm{GnRH}$ probe (diluted 1:1200), and yeast tRNA $(1.8 \mathrm{mg} / \mathrm{ml})$ in hybridization buffer] was applied to the tissue $(70 \mu \mathrm{l} / \mathrm{slide})$. The slides were covered with Parafilm, sealed with rubber cement, and incubated in humid chambers overnight at $68^{\circ} \mathrm{C}$. The next day the tissue was treated with RNase-A and washed under conditions of increasing stringency, including a $30 \mathrm{~min}$ wash at $65^{\circ} \mathrm{C}$ in $0.1 \times$ SSC. Next the sections were incubated for $60 \mathrm{~min}$ in blocking buffer, rinsed, and then incubated for $3 \mathrm{hr}$ at $37^{\circ} \mathrm{C}$ with anti-digoxigenin fragments conjugated to alkaline phosphatase (Boehringer Mannheim) diluted 1:1000. After rinsing, the sections were incubated in chromagen solution containing nitroblue tetrazolium-chloride (Boehringer Mannheim), 5-bromo-4-chloro-3-indolyl phosphate (Boehringer Mannheim), and levamisole. To stop the reaction, the sections were rinsed in $10 \mathrm{~mm}$ Tris containing $1 \mathrm{~mm}$ EDTA. Next, the slides were dipped in $70 \%$ ethanol, air-dried, dipped in 3\% parlodion followed by Kodak NTB-2 emulsion that was diluted 1:1 in $600 \mathrm{~mm}$ ammonium acetate, exposed for $7 \mathrm{~d}$, and developed.

${ }^{33}$ P-labeled $c$-fos and digoxigenin-labeled GnRH. We performed a double-label in situ hybridization to identify cells containing both $\mathrm{GnRH}$ mRNA and c-fos mRNA by the use of a protocol similar to that described in the preceding section with the following modifications. First, 35 
$\mu \mathrm{l} /$ slide hybridization buffer (without DTT) containing freshly denatured ${ }^{33} \mathrm{P}$-labeled c-fos probe $(538,000 \mathrm{dpm} / 1 \mu \mathrm{l}$ of hybridization solution), digoxigenin-labeled GnRH probe (diluted 1:4000), and yeast tRNA (1.8 $\mathrm{mg} / \mathrm{ml}$ ) was applied to the tissue. Second, the slides were covered with silane-coated coverslips and incubated overnight in humid containers at $60^{\circ} \mathrm{C}$. Third, the final stringent wash was performed in $0.1 \times \mathrm{SSC}$ at $60^{\circ} \mathrm{C}$. Fourth, the slides were dipped in Kodak NTB-3 and exposed for $52 \mathrm{~d}$.

\section{Control experiments}

The identity and integrity of all radioactively labeled cRNA probes were verified by PAGE against known standards. The control experiments used to validate the binding kinetics and specificity of the GnRH and galanin cRNA probes have been described previously (Marks et al., 1992), as have specificity experiments for the c-fos cRNA probe (Burton et al., 1995).

\section{Semiquantitative analysis of cellular galanin $m R N A$ levels in GnRH neurons}

Slides were assigned a random three-letter code and read in alphabetical order with an automated image-processing system by an operator unaware of the experimental group of the animal. The number of silver grains per cell was determined with a grain-counting program, as described previously (Marks et al., 1992).

In the double-label in situ hybridization assays, GnRH neurons were identified under bright-field illumination by the appearance of a purple precipitate in the cytoplasm, indicating the presence of the digoxigeninlabeled cRNA probe for GnRH mRNA. The silver grains overlying these GnRH neurons were counted under dark-field illumination by the computerized image processor, and their anatomical localization was noted. To minimize differences among experimental groups and to make conservative estimates of the changes in galanin mRNA levels (or c-fos mRNA levels), all identifiable GnRH neurons were analyzed for silver grain counts and included in the totals. This avoided making subjective decisions about whether a particular GnRH cell was double-labeled for galanin mRNA or c-fos mRNA. Thus, if not all GnRH neurons express galanin or c-fos mRNA, the grain counts would underestimate actual mRNA signal levels in the subset of GnRH neurons that do express the mRNAs. For galanin mRNA expression in GnRH neurons, 15 sections per animal, equally spaced from the diagonal band of Broca (DBB) through the caudal part of the preoptic area (POA), were analyzed for the number of grains per cell. For c-fos mRNA expression in GnRH neurons, nine sections per animal, equally spaced from the caudal DBB to the mid-POA, were analyzed for the number of grains per cell; this area contains the majority of GnRH neurons that express Fos at the time of an LH surge (Hoffman et al., 1990; Lee et al., 1990a).

In the single-label in situ hybridization assay for GnRH mRNA, 15 sections per animal, equally spaced from the DBB through the caudal part of the POA, were analyzed for the number of grains per cell. GnRH mRNA-expressing neurons were identified by the presence of a discrete grain cluster localized to areas in which GnRH neurons are found. The silver grains associated with clusters that had a signal-to-noise ratio $>10$ were counted under dark-field illumination by the computerized image processor, and their anatomical localization was noted. Two separate analyses were performed, based on the assignment of GnRH mRNAexpressing neurons to different anatomically described areas (Paxinos and Watson, 1986). In the first analysis, GnRH mRNA-expressing neurons were assigned to standard anatomically described areas, which included the DBB, POA, and medial septum. In the second analysis, GnRH mRNA-expressing neurons were assigned to areas based on their location within certain rostral-to-caudal divisions, which included the DBB (Plates 16 and 17), the rostral POA at the level of the vascular organ of the lamina terminalis (rPOA/OVLT; caudal to Plate 17 throught Plate 19), or the remaining POA (immediately caudal to Plate 19 to $\sim 0.08 \mathrm{~mm}$ rostral to Plate 21). This second analysis was undertaken to compare our results with those of two other laboratories that used a similar approach to study the regulation of GnRH gene expression at the time of an $\mathrm{LH}$ surge (Porkka-Heiskanen et al., 1994; Petersen et al., 1995).

\section{LH assay}

Serum levels of LH were measured under the auspices of the RIA core of the Population Center for Research in Reproduction at the University of Washington (Dr. William Bremner, Director) with reagents provided by National Institutes of Health. The standard was rLH-RP3, and the antiserum was anti-rLH-S11 (National Institute of Diabetes and Diges-

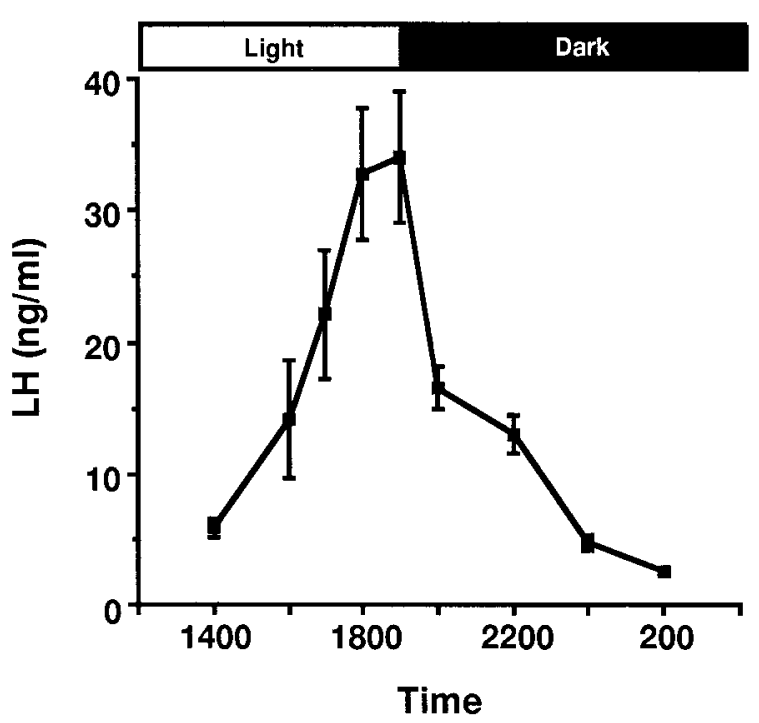

Figure 1. Time course of serum LH concentrations in estrogen- and progesterone-primed ovariectomized rats in experiment 1. Values represent the mean \pm SEM serum LH concentrations of serial blood samples obtained via jugular cannulae from 11 animals.

tive and Kidney Diseases, Bethesda, MD). The tracer was purchased from Corning Hazelton, Inc. (Vienna, VA). All samples were measured in a single assay. Based on the duplicate values of the samples run in the assay, the intraassay coefficient of variation was $4.5 \%$.

\section{Statistical analysis}

For the experiment, $n$ refers to the number of experimental animals within a group, and this $n$ was used for the analysis. For galanin, c-fos, and GnRH mRNA content determinations, the mean grains per cell from individual animals were used to calculate the mean \pm SEM for each group. Differences among groups in LH levels, numbers of cells counted, and grains per cell were assessed by ANOVA. When the ANOVA indicated a significant difference, Duncan's new multiple range test was used to detect differences between groups. The rejection level for statistical tests was set at $\alpha=0.05$.

\section{RESULTS}

\section{Experiment 1}

Serum LH levels in experiment 1 are shown in Figure 1. LH values began to rise by $1600 \mathrm{hr}$, peaked between 1800 and $1900 \mathrm{hr}$, and returned to baseline between 2200 and $2400 \mathrm{hr}$.

\section{Experiment 2}

\section{LH Levels}

Again, serum LH levels showed the pattern characteristic of a typical LH surge. As seen in Figure $2 A$, LH levels on day 2 were significantly higher in animals killed at $1600 \mathrm{hr}(n=6)$ than in animals killed earlier on that day $(p<0.05$ for $1600 \mathrm{hr}$ vs all earlier time points that day; $1200 \mathrm{hr}, n=4 ; 1400 \mathrm{hr}, n=6 ; 1500$ $\mathrm{hr}, n=6)$. Mean LH levels were highest at $1800 \mathrm{hr}(p<0.01 \mathrm{vs}$ $1600 \mathrm{hr} ; n=5)$ and returned to baseline by $2400 \mathrm{hr}(p<0.01 \mathrm{vs}$ $1600 \mathrm{hr}$ and $1800 \mathrm{hr} ; n=5)$. LH levels remained low at all time points sampled on day $3(0600 \mathrm{hr}, n=6 ; 1200 \mathrm{hr}, n=5 ; 1800 \mathrm{hr}$, $n=6)$.

\section{$c$-fos $m R N A$}

The c-fos mRNA content of GnRH neurons varied significantly over the nine time points that were sampled ( $p<0.001$; Fig. $2 B$ ). c-fos signal levels were twofold to sixfold higher on day 2 at 1600 hr than at any other time point sampled $(p<0.01$ vs all other time points). This increase in c-fos gene expression was coinci- 


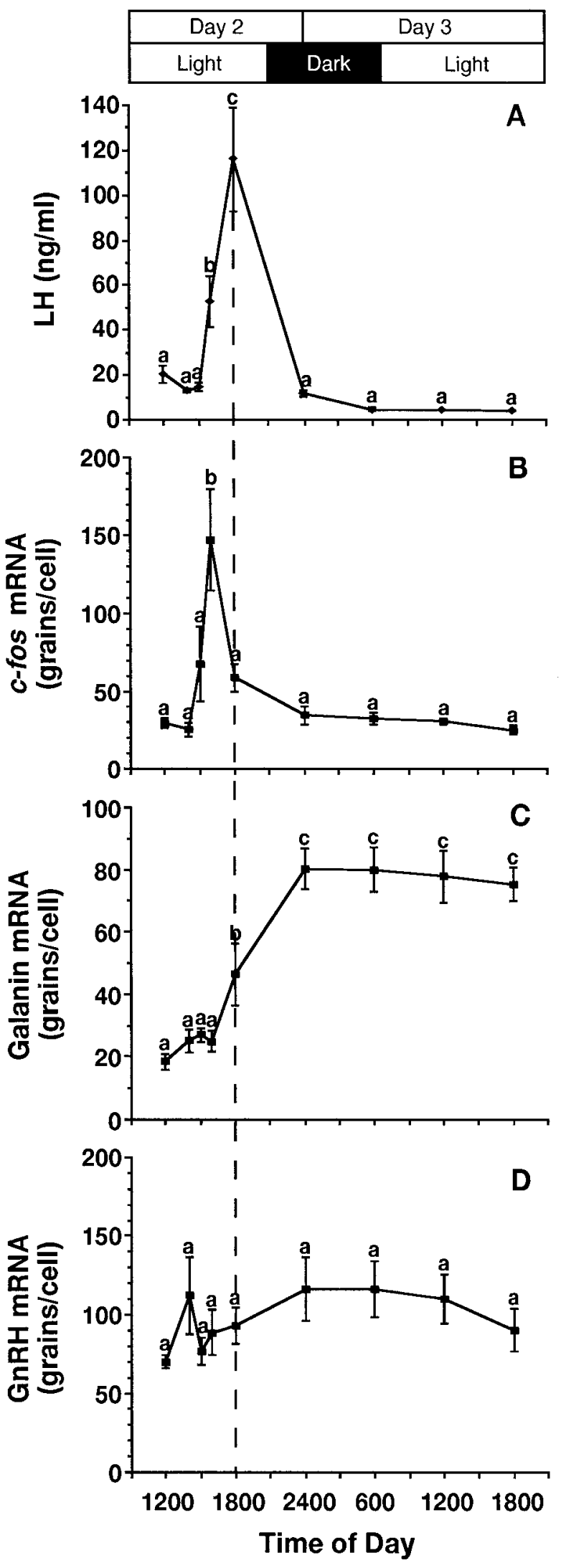

Figure 2. Time course of serum LH concentrations $(A)$, relative levels of c-fos mRNA $(B)$, relative levels of galanin mRNA $(C)$, and relative levels of GnRH mRNA $(D)$ in estrogen- and progesterone-primed ovariectomized rats during a $30 \mathrm{hr}$ period bracketing the time of the expected $\mathrm{LH}$ dent with the first significant increase in LH levels. Although c-fos mRNA levels appeared to be elevated on day 2 at both 1500 and $1800 \mathrm{hr}$ relative to the levels at 1200 and $1400 \mathrm{hr}$ on the same day, the apparent differences among these times were not statistically significant. The photomicrographs in Figure 3, $A$ and $B$, illustrate higher levels of c-fos mRNA expression in GnRH neurons at the beginning of the LH surge (day 2, $1600 \mathrm{hr}$ ) than subsequent (day 2, $2400 \mathrm{hr}$ ) to the LH surge (Fig. $3 E, F$ ). There were no significant differences among groups in the number of $\mathrm{GnRH}$ neurons counted.

\section{Galanin $m R N A$}

Galanin mRNA levels in GnRH neurons also differed significantly over the sampling period $(p<0.001)$. As illustrated in Figure $2 C$, animals killed at $1800 \mathrm{hr}$ on day 2 had twofold higher galanin mRNA signal levels in GnRH neurons than those killed earlier on day 2 ( $p<0.05$ for $1800 \mathrm{hr}$ vs all earlier time points that day). This initial increase in galanin mRNA in GnRH neurons coincided with maximal serum LH levels and occurred after c-fos mRNA in GnRH neurons had peaked. Levels of galanin mRNA in GnRH neurons increased another twofold by $2400 \mathrm{hr}$ on day 2 $(p<0.01$ vs $1800 \mathrm{hr})$ and remained elevated at all time points sampled on day 3 ( $p<0.01$ for $1800 \mathrm{hr}$ on day 2 vs all time points on day 3), well after the completion of the LH surge. The photomicrographs in Figure 3, $G$ and $H$, illustrate higher galanin mRNA in GnRH neurons after the peak of the LH surge (day 2, $2400 \mathrm{hr}$ ) than during the LH surge (day 2, $1600 \mathrm{hr}$ ) (Fig. 3C,D). There were no significant differences among the groups in the number of GnRH neurons counted.

\section{GnRH mRNA levels}

GnRH mRNA levels did not differ significantly among groups, whether analyzed by brain area or by the time of killing relative to the LH surge ( $p>0.05$; Fig. $2 D$ ). There were no differences among groups in the number of GnRH mRNA-expressing cells counted across the nine time points sampled bracketing the $\mathrm{LH}$ surge. Because other laboratories have reported finding differences in GnRH mRNA expression when their analysis was restricted to specific areas (Porkka-Heiskanen et al., 1994; Petersen et al., 1995), we performed an analysis similar to these others and again could detect no significant differences among groups in either the number of GnRH mRNA-containing neurons counted $(p>0.05)$ or the level of GnRH mRNA measured per cell for the $\mathrm{DBB}$, the $\mathrm{rPOA} / \mathrm{OVLT}$, or the remaining POA $(p>0.05)$.

\section{DISCUSSION}

We report here that levels of c-fos mRNA in GnRH neurons are elevated significantly coincident with the first increase in $\mathrm{LH}$ levels at the time of an E- and P-induced LH surge in female rats. Similarly, Fos protein increases in GnRH neurons near the time of the LH surge in rats (Lee et al., 1990a; Hrabovszky et al., 1995; Wang et al., 1995), mice (Wu et al., 1992), hamsters (Berriman et al., 1992; Doan and Urbanski, 1994), and sheep (Moenter et al., 1993). In rats, Fos protein is first detectable in GnRH neurons after the onset of the expected $\mathrm{LH}$ surge, and the number of surge (experiment 2). Values represent the mean \pm SEM of four to six animals per group. Values with different letters are significantly different from one another $(p<0.05)$. Values with the same letter are not significantly different from one another $(p>0.05)$. The dashed line indicates the time of the peak of the LH surge. 


\section{$1600 \mathrm{~h}$}

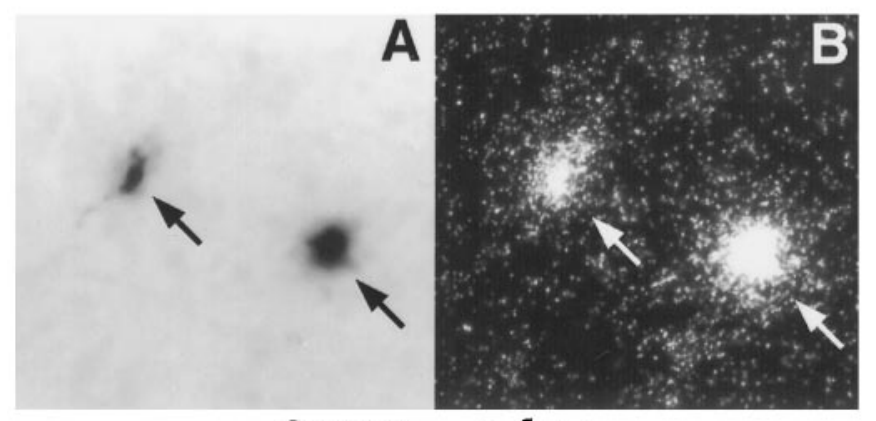

GnRH - c-fos

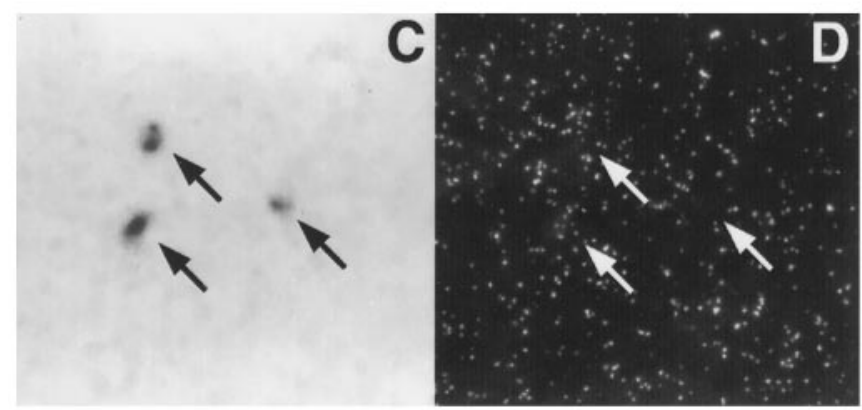

GnRH - Galanin

\section{$2400 \mathrm{~h}$}

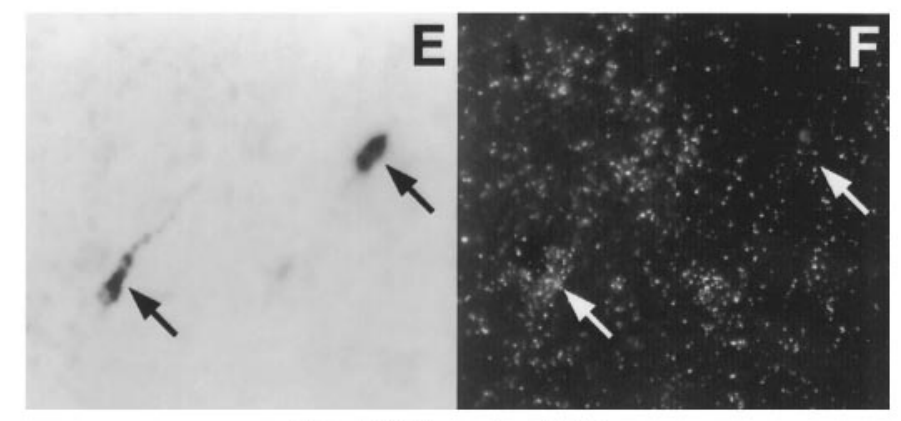

GnRH - c-fos

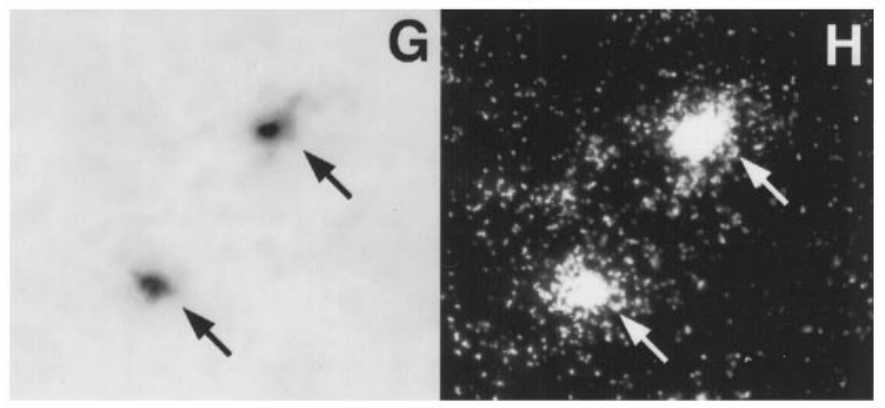

GnRH - Galanin

Figure 3. A, Bright-field photomicrograph of two GnRH neurons (black arrows) labeled with a digoxigenin-labeled cRNA probe for GnRH mRNA in an ovariectomized estrogen- and progesterone-primed female rat killed at $1600 \mathrm{hr}$ on the day of the expected LH surge. $B$, Dark-field photomicrograph of the same view as in $A$ showing the location of the same two GnRH neurons labeled with a ${ }^{33} \mathrm{P}$-labeled probe for c-fos mRNA (white arrows). Note the abundance of silver grains (clusters of white dots) over each cell indicating the high level of c-fos mRNA expression in these neurons. $C$, Bright-field photomicrograph of three GnRH neurons (black arrows) labeled with a digoxigenin-labeled cRNA probe for GnRH mRNA in the same animal shown in $A$ and $B . D$, Dark-field photomicrograph of the same view as $C$, showing the location of the same three GnRH neurons labeled with a ${ }^{35} \mathrm{~S}$-labeled probe for galanin mRNA (white arrows). Note the relative absence of silver grains indicating the low level of galanin mRNA expression in these neurons. $E$, Bright-field photomicrograph of two GnRH neurons (black arrows) labeled with a digoxigenin-labeled cRNA probe for GnRH mRNA in an ovariectomized estrogen- and progesterone-primed female rat killed at $2400 \mathrm{hr}$ on the day of the expected LH surge. $F$, Dark-field photomicrograph of the same view as in $E$ showing the location of the same two GnRH neurons labeled with a ${ }^{33} \mathrm{P}$-labeled probe for c-fos mRNA (white arrows). Note the relative absence of silver grains indicating the low level of c-fos mRNA expression in these neurons. $G$, Bright-field photomicrograph of two GnRH neurons (black arrows) labeled with a digoxigenin-labeled cRNA probe for GnRH mRNA in the same animal shown in $E$ and $F$. $H$, Dark-field photomicrograph of the same view as $G$, showing the location of the same two GnRH neurons labeled with a ${ }^{35}$ S-labeled probe for galanin mRNA (white arrows). Note the abundance of silver grains (clusters of white dots) over each cell indicating the high level of galanin mRNA expression in these neurons. Magnification, $1200 \times$.

GnRH neurons expressing Fos increases during the ascending phase of the LH surge (Lee et al., 1990a, 1992b). These results agree with those of the present study showing that c-fos gene expression increases in GnRH neurons near the onset of the $\mathrm{LH}$ surge. Synaptic blockade with phenobarbital or MK-801 (an NMDA channel blocker) inhibits the LH surge and the induction of Fos in GnRH neurons (Lee et al., 1990a, 1993), suggesting that this induction is dependent on trans-synaptic activation of $\mathrm{GnRH}$ neurons. GnRH neurons also express Jun concomitantly with the LH surge (Lee et al., 1992a). Together, Fos and Jun form a heterodimer, activator protein 1 (AP-1), that regulates a variety of genes (Morgan and Curran, 1991). Among the possible targets for AP-1 regulation in GnRH neurons is the gene for galanin, which has elements in the $5^{\prime}$-flanking region that can bind members of the Fos/Jun family of transcription factors (Anouar et al., 1994), and the gene for GnRH itself, which has an AP-1 site in its upstream regulatory region (Bond et al., 1989).

GnRH levels in the portal circulation increase before the onset of the LH surge (see Freeman, 1994); however, it is unclear whether this increase is associated with alterations in GnRH gene expression (see Sagrillo et al., 1996). In the present study, we detected no significant differences in $\mathrm{GnRH}$ gene expression across a $30 \mathrm{hr}$ period bracketing an E- and P-induced LH surge (6 hr before and $24 \mathrm{hr}$ after), either by the number of detectable GnRH mRNA-expressing neurons or by signal levels of $\mathrm{GnRH}$ mRNA per cell. Similarly, two other laboratories found no differences in cytoplasmic GnRH mRNA levels at the time of a Eand P-induced LH surge, as measured by RNase protection assay (Gore and Roberts, 1995) or by in situ hybridization (Park et al., 1990). However, a third laboratory found that GnRH mRNA levels in the rPOA/OVLT and POA increased $\sim 8 \mathrm{hr}$ before a steroid-induced LH surge (Petersen et al., 1995), earlier than we began sampling and which would have gone unrecognized in our study. The results of studies examining levels of GnRH mRNA relative to a preovulatory LH surge are more contradictory. Although our laboratory (Marks et al., 1993) and Malik and colleagues (1991) found no differences in GnRH mRNA over the estrous cycle, others have found that GnRH mRNA levels in- 
crease before or at the time of a preovulatory LH surge in at least a subset of GnRH neurons (Zoeller and Young, 1988; Park et al., 1990; Porkka-Heiskanen et al., 1994; Gore and Roberts, 1995; Suzuki et al., 1995). However, these reports disagree with one another on detailed aspects of this putative phenomenon (see Sagrillo et al., 1996). If it is true that GnRH mRNA levels increase on the day of the LH surge, the consensus of the studies that testify to finding such an increase would have it occur several hours before the induction of c-fos mRNA (reported here) and Fos protein in GnRH neurons (Lee et al., 1992b; PorkkaHeiskanen et al., 1994; Gore and Roberts, 1995; Petersen et al., 1995). Thus, it would be unlikely that Fos is involved in the induction of GnRH gene expression.

On the basis of several observations, Fos may be involved in the induction of galanin gene expression in GnRH neurons. First, like Fos, galanin mRNA levels in GnRH neurons increase coincident with a preovulatory or steroid-induced LH surge (Hoffman et al., 1990; Lee et al., 1990a; Marks et al., 1993, 1994), and galanin mRNA is expressed in the majority of GnRH neurons that colocalize Fos at the time of a steroid-induced LH surge (Hrabovszky et al., 1995). Second, blockade of the steroidinduced LH surge with either phenobarbital or MK-801 is associated with an inhibition of Fos protein and galanin gene expression in GnRH neurons (Lee et al., 1990a, 1993; Marks et al., 1994; Rossmanith et al., 1996a). Third, in E-primed rats, P increases both the number of GnRH neurons that express Fos and the level of galanin gene expression in GnRH neurons (Lee et al., 1990b; Rossmanith et al., 1996b). Finally, we demonstrate here that the first detectable rise in galanin mRNA levels in GnRH neurons occurs 2 hr after c-fos mRNA rises in GnRH neurons, providing sufficient time for translation of c-fos mRNA into Fos protein and the initiation of galanin gene expression by an AP-1-dependent mechanism. Therefore, we postulate that the induction of c-fos mRNA in GnRH neurons at the time of the LH surge is involved directly in the activation of galanin gene expression in $\mathrm{GnRH}$ neurons.

Here we show that galanin mRNA levels in GnRH neurons increase only after the onset of the LH surge and remain elevated for at least $24 \mathrm{hr}$, confirming our previous observation that galanin mRNA levels in GnRH neurons increase between the morning and afternoon of proestrus and are elevated $24 \mathrm{hr}$ later on estrus (Marks et al., 1993). This increase could reflect an increase in galanin gene transcription or a decrease in mRNA degradation, but regardless of the mechanism, there is more galanin mRNA in GnRH neurons for possible translation into protein. However, the time course of galanin protein levels in $\mathrm{GnRH}$ neurons relative to an LH surge is unclear. Merchenthaler and colleagues (1991), using immunocytochemistry, found no difference in the number of GnRH neurons that colocalize galanin over the estrous cycle. However, the interpretation of this "negative" result is complicated by two factors. First, colchicine, which by itself can induce galanin mRNA (Cortes et al., 1990), was used to visualize galanin in GnRH neurons. Second, double-label immunocytochemistry may not be sufficiently sensitive to detect small changes in protein levels. Therefore, although galanin mRNA in GnRH neurons is increased dramatically in association with an LH surge, the consequences of this transcriptional regulation on galanin peptide production await further clarification.

We have proposed that the galanin deriving from $\mathrm{GnRH}$ neurons is needed for the production of an LH surge. This is supported by the observations that galanin stimulates $\mathrm{GnRH}$ from median eminence fragments (López and Negro-Vilar, 1990;
Merchenthaler et al., 1990; Sahu et al., 1994), central infusions of galanin stimulate LH secretion in E-primed rats (Sahu et al., 1987, 1994), galanin antagonists and antiserum blunt the LH surge (López et al., 1993; Sahu et al., 1994), and galanin mRNA expression in GnRH neurons is inhibited by pharmacological agents that block the LH surge (Marks et al., 1994; Rossmanith et al., 1996a). Therefore, we expected galanin mRNA levels in $\mathrm{GnRH}$ neurons to rise before the LH surge. It is possible that galanin gene expression in GnRH neurons increases in response to the depletion of galanin stores that occurs during the early stages of the GnRH and LH surge. If this is the case, then it is puzzling that levels of galanin mRNA remain elevated for so long after the onset of the LH surge $(>24 \mathrm{hr})$. Under laboratory conditions, female rats undergo a preovulatory surge of LH every 4-5 d (see Freeman, 1994), whereas in the wild, they are more likely to show preovulatory surges at much longer intervals, with the majority of the intervening time spent in pregnancy or lactation. Thus, it is reasonable to postulate that the increase of galanin mRNA at the time of the LH surge reflects a need for the production of galanin to be involved in processes that occur subsequent to the $\mathrm{LH}$ surge rather than in replenishing galanin stores that would be used to generate the next LH surge; this remains to be explored.

The present results suggest that the expression of Fos protein in GnRH neurons is a reflection of events culminating in the hypersecretion of GnRH, and that Fos is involved in the activation of galanin, but not GnRH, gene expression in GnRH neurons. We postulate that the increase in galanin mRNA levels in GnRH neurons at the time of the LH surge reflects either the need to replenish galanin stores depleted during the preceding LH surge or the prolonged production of galanin required to serve physiological events occurring on the day of estrus or thereafter.

\section{REFERENCES}

Adelman JP, Mason AJ, Hayflick JS, Seeburg PH (1986) Isolation of the gene and hypothalamic cDNA for the common precursor of gonadotropin-releasing hormone and prolactin release-inhibiting factor in human and rat. Proc Natl Acad Sci USA 83:179-183.

Anouar Y, MacArthur L, Cohen J, Iacangelo AL, Eiden LE (1994) Identification of a TPA-responsive element mediating preferential transactivation of the galanin gene promoter in chromaffin cells. J Biol Chem 269:6823-6831.

Berriman SJ, Wade GN, Blaustein JD (1992) Expression of Fos-like proteins in gonadotropin-releasing hormone neurons of Syrian hamsters: effects of estrous cycles and metabolic fuels. Endocrinology 131:2222-2228.

Bond CT, Hayflick JS, Seeburg PH, Adelman JP (1989) The rat gonadotropin-releasing hormone: SH locus: structure and hypothalamic expression. Mol Endocrinol 3:1257-1262.

Burton KA, Kabigting EB, Steiner RA, Clifton DK (1995) Identification of target cells for growth hormone's action in the arcuate nucleus. Am J Physiol 269:E716-E722.

Coen C, Montagnese C, Opacka-Juffry J (1990) Coexistence of gonadotropin-releasing hormone and galanin: immunohistochemical and functional studies. J Neuroendocrinol 2:107-111.

Cortes R, Ceccatelli S, Schalling M, Hokfelt T (1990) Differential effects of intracerebroventricular colchicine administration on the expression of mRNAs for neuropeptides and neurotransmitter enzymes, with special emphasis on galanin: an in situ hybridization study. Synapse 6:369-391.

Curran T, Gordon MB, Rubino KL, Sambucetti LC (1987) Isolation and characterization of the c-fos (rat) cDNA and analysis of posttranslational modification in vitro. Oncogene 2:79-84.

Doan A, Urbanski HF (1994) Diurnal expression of Fos in luteinizing hormone-releasing hormone neurons of Syrian hamsters. Biol Reprod 50:301-308.

Finn PD, McFall TB, Clifton DK, Steiner RA (1996) Sexual differenti- 
ation of galanin gene expression in gonadotropin-releasing hormone neurons. Endocrinology 137:4767-4772.

Freeman ME (1994) The neuroendocrine control of the ovarian cycle of the rat. In: The physiology of reproduction (Knobil E, Neill JD, eds), pp 613-658. New York: Raven.

Gore AC, Roberts JL (1995) Regulation of gonadotropin-releasing hormone gene expression in the rat during the luteinizing hormone surge. Endocrinology 136:889-896.

Hoffman GE, Lee W-S, Attardi B, Yann V, Fitzsimmons MD (1990) Luteinizing hormone-releasing hormone neurons express c-fos antigen after steroid activation. Endocrinology 126:1736-1741.

Hrabovszky E, Vrontakis ME, Peterson SL (1995) Triple-labeling method combining immunocytochemistry and in situ hybridization histochemistry: demonstration of overlap between Fos-immunoreactive and galanin mRNA-expressing subpopulations of luteinizing hormonereleasing hormone neurons in female rats. J Histochem Cytochem 43:363-370.

Lee W-S, Smith MS, Hoffman GE (1990a) Luteinizing hormonereleasing hormone neurons express Fos protein during the proestrous surge of luteinizing hormone. Proc Natl Acad Sci USA 87:5163-5167.

Lee W-S, Smith MS, Hoffman GE (1990b) Progesterone enhances the surge of luteinizing hormone by increasing the activation of luteinizing hormone-releasing hormone neurons. Endocrinology 127:2604-2606.

Lee W-S, Abbun R, Smith MS, Hoffman GE (1992a) LHRH neurons express cJun protein during the proestrous surge of luteinizing hormone. Endocrinology 130:3101-3103.

Lee W-S, Smith MS, Hoffman GE (1992b) cFos activity identifies recruitment of luteinizing hormone releasing hormone neurons during the ascending phase of the proestrous luteinizing hormone surge. J Neuroendocrinol 4:161-166.

Lee W-S, Abbud R, Hoffman GE, Smith MS (1993) Effects of $N$-methylD-aspartate receptor activation on cFos expression in luteinizing hormone-releasing hormone neurons in female rats. Endocrinology 133:2248-2254.

López FJ, Negro-Vilar A (1990) Galanin stimulates luteinizing hormone-releasing hormone secretion from arcuate nucleus-median eminence fragments in vitro: involvement of an $\alpha$-adrenergic mechanism. Endocrinology 127:2431-2436.

López FJ, Meade EH, Negro-Vilar A (1993) Endogenous galanin modulates the gonadotropin and prolactin proestrous surges in the rat. Endocrinology 132:795-800.

Malik KF, Silverman A-J, Morrell JI (1991) Gonadotropin releasing hormone mRNA in the rat: distribution and neuronal content over the estrous cycle and after castration in males. Anat Rec 231:457-466.

Marks DL, Weimann JN, Burton KA, Lent KL, Clifton DK, Steiner RA (1992) Simultaneous visualization of two cellular mRNA species in individual neurons by use of a new double in situ hybridization method. Mol Cell Neurosci 3:395-405.

Marks DL, Smith MS, Vrontakis M, Clifton DK, Steiner RA (1993) Regulation of galanin gene expression in gonadotropin-releasing hormone neurons during the estrous cycle of the rat. Endocrinology 132:1836-1844.

Marks DL, Lent KL, Rossmanith WG, Clifton DK, Steiner RA (1994) Activation-dependent regulation of galanin gene expression in gonadotropin-releasing hormone neurons in the female rat. Endocrinology 134:1991-1998.

Merchenthaler I, Lopez FJ, Negro-Vilar A (1990) Colocalization of galanin and luteinizing hormone-releasing hormone in a subset of preoptic hypothalamic neurons: anatomical and functional correlates. Proc Natl Acad Sci USA 87:6326-6330.

Merchenthaler I, López FJ, Lennard DE, Negro-Vilar A (1991) Sexual differences in the distribution of neurons coexpressing galanin and luteinizing hormone-releasing hormone in the rat brain. Endocrinology 129:1977-1986.

Moenter SM, Karsch FJ, Lehman MN (1993) Fos expression during the estradiol-induced gonadotropin-releasing hormone $(\mathrm{GnRH})$ surge of the ewe: induction in GnRH and other neurons. Endocrinology 133:896-903.

Morgan JI, Curran T (1991) Stimulus-transcription coupling in the nervous system: involvement of the inducible proto-oncogenes fos and jun. Annu Rev Neurosci 14:421-451.

Park O-K, Gugneja S, Mayo KE (1990) Gonadotropin-releasing hormone gene expression during the rat estrous cycle: effects of pentobarbitol and ovarian steroids. Endocrinology 127:365-372.

Paxinos G, Watson C (1986) The rat brain in stereotaxic coordinates. New York: Academic.

Petersen SL, McCrone S, Keller M, Shores S (1995) Effects of estrogen and progesterone on luteinizing hormone-releasing hormone messenger ribonucleic acid levels: consideration of temporal and neuroanatomical variables. Endocrinology 136:3604-3610.

Porkka-Heiskanen T, Urban JH, Turek FW, Levine JE (1994) Gene expression in a subpopulation of luteinizing hormone-releasing hormone (LHRH) neurons prior to the preovulatory gonadotropin surge. J Neurosci 14:5548-5558.

Rossmanith WG, Marks DL, Steiner RA, Clifton DK (1996a) Inhibition of steroid-induced galanin mRNA expression in GnRH neurons by a specific NMDA-receptor blockade. J Neuroendocrinol 8:179-184.

Rossmanith WG, Marks DL, Clifton DK, Steiner RA (1996b) Induction of galanin mRNA in GnRH neurons by estradiol and its facilitation by progesterone. J Neuroendocrinol 8:185-191.

Sagrillo CA, Grattan DR, McCarthy MM, Selmanoff M (1996) Hormonal and neurotransmitter regulation of $\mathrm{GnRH}$ gene expression and related reproductive behaviors. Behav Genet 26:241-277.

Sahu A, Crowley WR, Tatemoto K, Balasubramaniam A, Kalra SP (1987) Effects of neuropeptide Y, NPY analog (norleucine4-NPY), galanin and neuropeptide $\mathrm{K}$ on LH release in ovariectomized (ovx) and ovx estrogen, progesterone-treated rats. Peptides 8:921-926.

Sahu A, Xu B, Kalra SP (1994) Role of galanin in stimulation of pituitary luteinizing hormone secretion as revealed by a specific receptor antagonist, galantide. Endocrinology 134:529-536.

Steiner RA, Bremner WJ, Clifton DK (1982) Regulation of luteinizing hormone pulse frequency and amplitude by testosterone in the adult male rat. Endocrinology 111:2055-2061.

Suzuki M, Nishihara M, Takahashi M (1995) Hypothalamic gonadotropin-releasing hormone gene expression during the rat estrous cycle. Endocr J 42:789-796.

Vrontakis ME, Peden LM, Duckworth ML, Friesen HG (1987) Isolation and characterization of a complimentary DNA (galanin) clone from estrogen-induced pituitary tumor messenger RNA. J Biol Chem 262:16755-16758.

Wang H-J, Hoffman GE, Smith MS (1995) Increased GnRH mRNA in the GnRH neurons expressing cFos during the proestrous LH surge. Endocrinology 136:3673-3676.

Wiemann JN, Clifton DK, Steiner RA (1990) Gonadotropin-releasing hormone messenger ribonucleic acid levels are unaltered with changes in the gonadal hormone milieu of the adult male rat. Endocrinology 127:523-532.

Wu TJ, Segal AZ, Miller GM, Gibson MJ, Silverman A-J (1992) FOS expression in gonadotropin-releasing hormone neurons: enhancement by steroid treatment and mating. Endocrinology 131:2045-2050.

Zoeller RT, Young WS (1988) Changes in cellular levels of messenger ribonucleic acid encoding gonadotropin releasing hormone in the anterior hypothalamus of female rats during the estrous cycle. Endocrinology 123:1688-1689. 